\title{
Distribution of the dinoflagellate parasite Parvilucifera infectans (Perkinsozoa) along the Swedish coast
}

\author{
Mona Johansson, Alexander Eiler, Lars Tranvik, Stefan Bertilsson* \\ Limnology/Department of Ecology and Evolution, Evolutionary Biology Centre, Uppsala University, Norbyvägen 20, \\ 75236 Uppsala, Sweden
}

\begin{abstract}
Dinoflagellate parasites, e.g. Parvilucifera infectans Norén et Moestrup, 1996 can potentially control dinoflagellate blooms and thereby modify plankton communities and nutrient fluxes. Parvilucifera infectans has been detected in Swedish waters, but its distribution is largely unknown. Based on 18S rRNA sequences of 2 P. infectans isolates of different geographic origin (Sweden and Tasmania), we designed 2 primer pairs for specific PCR amplification of rRNA fragments from these parasites. We screened for presence of $P$. infectans in a salinity gradient along the Swedish coastline ( 2 to $30 \%$, 13 stations) from June to August 2004. Parasites were only detected in July and August at 3 stations in the region with highest salinity (Skagerrak). Presence of parasites was correlated with high abundances of dinoflagellate hosts (Prorocentrum spp., Ceratium spp.) but was also restricted to warm and saline waters. In addition, these stations were characterized by low bacterial abundances, low chl $a$ and low nutrient levels. Parasites were not detected in this region in June, when temperatures were lower $\left(<15^{\circ} \mathrm{C}\right)$ and microzooplankton predators were most abundant. Hence, our study reveals both temporal and spatial patchiness of $P$. infectans in coastal waters.
\end{abstract}

KEY WORDS: Parvilucifera infectans - Eukaryotic parasite $\cdot 18 \mathrm{~S}$ rRNA probe $\cdot$ Dinoflagellate · Harmful algal bloom · Skagerrak · Öresund $\cdot$ Baltic Sea

Resale or republication not permitted without written consent of the publisher

\section{INTRODUCTION}

Dinoflagellates are major constituents of plankton communities and often cause dense blooms, which are sometimes toxic or otherwise harmful, e.g. by clogging the gills of fish (Granéli et al. 1987, Richardson 1997). The mechanisms of bloom dynamics are not fully understood, but excess nutrients, specific hydrographical events, competition, grazing pressure, viruses and bacteria are some critical factors (Watras et al. 1985, Kim et al. 1998, Jeong et al. 1999a,b, Nagasaki et al. 1999). Recently, eukaryotic parasites e.g. Amoebophrya spp. (Dinophyta) and Parvilucifera infectans Norén et Moestrup, 1996 (Perkinsozoa), have also been recognised as having the potential to prevent or terminate dinoflagellate blooms (Coats 1999, Park et al. 2004).

Eukaryotic parasites have been recognized since 1885 (Pouchet 1885), whereas studies of their ecology and ability to regulate dinoflagellate blooms in marine environments began in the 1980s (Nishitani at al 1985, Coats \& Bockstahler 1994, Coats et al. 1996, Salomon et al. 2003a). The parasites infect the dinoflagellates with small (5 to $7 \mu \mathrm{m}$ ) flagellated infective stages that penetrate the dinoflagellate, multiply inside the host, and eventually produce numerous (200 to 700 ) new infective flagellates (Cachon 1964, Norén et al. 1999). Once infected, the dinoflagellates are unable to reproduce and die within days (Elbrächter 1973, Cachon \& Cachon 1987, Coats \& Bockstahler 1994, Norén et al. 1999).

Most current knowledge of the ecology of eukaryotic parasites on dinoflagellates comes from studies of Amoebophrya ceratii (see Coats 1999, Park et al. 2004 and references therein). A. ceratii is considered to be a complex of species that are typically host-species specific (Coats et al. 1996, Jansson et al. 2000, Coats \& 
Park 2002, Gunderson et al. 2002, Salomon et al. 2003b) and have been shown to infect over 30 different dinoflagellate species (see Park et al. 2004 and references therein). However, some isolates have also successfully infected several different species of dinoflagellates (Sengco et al. 2003). This parasite is found globally (Park et al. 2004 and references therein), and occasionally in high numbers, resulting in 30 to $80 \%$ of host cells being infected (Taylor 1968, Nishitani et al. 1985, Coats et al. 1996). High rate of infection is associated with high densities of the dinoflagellate host (Cachon 1964, Taylor 1968, Nishitani et al. 1985, Coats et al. 1996), whereas vertical separation of host and parasites (Coats \& Bockstahler 1994) and microzooplankton preying on the infective stage of the parasite decrease infection (Maranda 2001, Johansson \& Coats 2002).

In 1996, a new eukaryotic parasite, Parvilucifera infectans, was discovered at the west coast of Sweden (Norén et al. 1999). This parasite species has the potential to affect many dinoflagellate species, since it does not seem to be host-species specific (Norén et al. 2000). So far, in natural plankton samples, $P$. infectans has been identified in 17 species of dinoflagellates, of which a few are toxic or otherwise harmful (Nishitani et al. 1985, Berland et al. 1995, Delgado 1999, Norén et al. 1999, 2000, Erard-Le Denn et al. 2000, Park et al. 2004). In the laboratory, $P$. infectans has successfully infected 9 additional species (Berland et al. 1995, Delgado 1999, Norén et al. 1999, 2000, Erard-Le Denn et al. 2000). The distribution of $P$. infectans-like parasites seems global, with reports of its occurrence in Skagerrak (Swedish west coast), North Sea (Norwegian west coast and off the Danish coast), the Atlantic coast, the Mediterranean Sea, the Indian Ocean, eastern North America (Narragansett Bay), Australia, and the southern coastal waters of Korea (Norén et al. 2000, Park et al. 2004, Salomon 2004). In a declining North Sea bloom of Dinophysis norvegica, $20 \%$ of cells were infected by $P$. infectans, suggesting that parasitism could be an important loss factor contributing to bloom dissipation (Gisselson et al. 2002). Since its discovery, $P$. infectans has been observed several times in plankton samples from the Swedish west coast (M. Johansson unpubl. data). However, the spatial distribution of $P$. infectans along a continuous coastline has not been reported and there have been no previous attempts to screen for the presence of $P$. infectans in less saline environments such as brackish waters of the Baltic Sea.

In the present study, we screened for the parasite Parvilucifera infectans along a salinity gradient (2 to $30 \%$ ) along the Swedish coastline during summer 2004 (June to August). Identification of the parasite is usually carried out by microscopy, but this procedure is tedious and difficult and detects only the late stages of parasitism. Hence, microscopic surveys may overlook or at least underestimate parasite prevalence. Therefore, we developed a PCR-based method that is independent of microscopy and culturing, in order to rapidly identify this parasite in natural surface waters. Based on 18S rRNA sequences of $2 P$. infectans isolates of different geographic origin (Sweden and Tasmania), we designed 2 primers for specific PCR amplification of a partial 18S rRNA fragment from these parasites. Parasite occurrence was then compared to physical, chemical and biological data from the same sampling dates to identify factors that potentially control $P$. infectans prevalence in northern coastal waters.

\section{MATERIALS AND METHODS}

Study area and sampling. Samples were taken along the Swedish coastline at a total of 13 different stations along a salinity gradient (2 to $30 \%$ ), from June to August 2004 (Fig. 1, see Table 2). On each occasion, samples were taken for parasites, microzooplankton, phytoplankton, bacteria, chlorophyll, temperature, salinity, oxygen, secchi depth, and total nitrogen, phosphorus and organic carbon. For the biological and chemical analysis, integrated water samples were taken from the upper $20 \mathrm{~m}$ of the water column. To achieve integrated water samples, we used either a plastic (PVC approved for human food) tube equipped with a weight at the lower end that was slowly lowered by hand at a constant rate to 10 to $20 \mathrm{~m}$ depth, and stoppered at the upper end before being retrieved (Skagerrak, Bothnian Sea, Bothnian Bay), or Ruttnertype water samplers lowered to $0,5,10,15$, and $20 \mathrm{~m}$ depth from which equal amounts of water were mixed (northern Baltic proper). In Öresund, a tube was used for the top $10 \mathrm{~m}$, and a Ruttner-type water sampler at 12,14 , and $20 \mathrm{~m}$ depth. In the central Baltic proper, water was pumped from 0, 5, 10, 15, 20, 25 and $30 \mathrm{~m}$ depth, and equal amounts of water were mixed.

Temperature, salinity, and oxygen. Temperature $\left({ }^{\circ} \mathrm{C}\right)$ and salinity (ppt) were measured in depth profiles with a YSI 33 (Yellow Spring Instruments) in Skagerrak and a CTD-profiler at remaining stations, except in the central Baltic proper where only temperature was measured at discrete depths.

Oxygen was measured in replicate samples with a modified Winkler method (Granéli \& Granéli 1991) in the Bothnian Bay and Bothnian Sea, a few meters from the bottom. In Skagerrak and the northern Baltic proper, oxygen $\left(\mathrm{mg} \mathrm{l}^{-1}\right)$ was measured in depth profiles with a YSI 58 (Yellow Spring Instruments) and nearbottom values were used.

Nutrients. Three replicate $20 \mathrm{ml}$ water samples from each of the integrated water samples were immedi- 




Fig. 1. Sampling areas. SK: Skagerrak stations A-C, Ore: Öresund station, CBp: central Baltic proper station, NBp: northern Baltic proper stations A-C, BS: Bothnian Sea stations A-C, BB: Bothnian Bay stations A-B

ately frozen $\left(-20^{\circ} \mathrm{C}\right)$ in acid-washed $(10 \% \mathrm{HCl})$ plastic bottles $(20 \mathrm{ml})$ until analysed. Total organic carbon (TOC) was measured in a Shimadzu TOC 5000 organic carbon analyser. Inorganic carbon was removed with acid $\left(8.3 \mu \mathrm{l} 1.2 \mathrm{M} \mathrm{HCl} \mathrm{ml}^{-1}\right)$ and 7 min purging with $\mathrm{CO}_{2}$-free air. Total nitrogen (Tot-N) was measured in an Antek 9000 total nitrogen analyser (Antek Instruments) Total phosphorus (Tot-P) was measured according to Menzel \& Corwin (1965) and Murphy \& Riley (1962).

Bacteria. Subsamples $(20 \mathrm{ml})$ of each integrated water sample were fixed with $2 \%$ final concentration of borate-buffered, $0.2 \mu \mathrm{m}$ filtered formaldehyde, in triplicate acid-washed $(10 \% \mathrm{HCl})$ plastic vials that were kept dark and cold $\left(4^{\circ} \mathrm{C}\right)$ until analysed. The concentration of bacterial cells was analysed by flow cytometry using nucleic acid stain Syto 13 (Del Giorgio et al. 1996). A calibrated solution of fluorescent beads (Fluoresbrite Carboxy YG, $1.64 \mu \mathrm{m}$ diameter) was added to each sample as an internal standard. For each sample, at least 5000 cells were counted on a FACScan flow cytometer (Becton Dickinson). Cells were separated from noise and fluorescent beads in a double logarithmic plot of side scatter and green fluorescence. The coefficient of variation for quadruplicate samples was $2.5 \%$. In a subset of samples that was analysed by both flow cytometry and by DAPI-staining and fluorescence microscopy (Porter \& Feig 1980), the 2 measures were highly correlated $\left(r^{2}=0.92, n=9\right)$ with a near $1: 1$ slope (0.98).

Chl $a$, phytoplankton and microzooplankton. For chl $a, 1$ to $2 \mathrm{l}$ of the integrated water samples were filtered onto 2 replicate GF/F filters ( $47 \mathrm{~mm}$, Whatman) and immediately frozen $\left(-80^{\circ} \mathrm{C}\right)$ until analysed. $\mathrm{Chl} \mathrm{a}$ was extracted with $10 \mathrm{ml}$ of ethanol in darkness at room temperature overnight with intermittent mixing of tubes. Extracts were cleared by centrifugation $(2000 \times g, 10 \mathrm{~min})$. Chl a was measured by fluorescence (Holm-Hansen \& Riemann 1978) on a Fluoromax-2 spectrofluorometer (Spex) equipped with an external microplate reader. Fluorescence was calibrated against an ethanol extract of Geranium sp. 
leaves (Wintermanns \& DeMots 1965, Jespersen \& Christoffersen 1987).

For identification and counting of phytoplankton and microzooplankton in integrated water samples, 150 to $250 \mathrm{ml}$ were fixed with $1 \%$ acid Lugol's solution and kept cold $\left(4^{\circ} \mathrm{C}\right)$ until analysed. The samples (50 to $100 \mathrm{ml}$ ) were counted under an inverted microscope (200 to $400 \times$ magnification) in a settling chamber (Utermöhl 1958). The entire chamber or at least 100 individuals of each species was counted. All dinoflagellates, diatoms, large flagellates (>15 $\mu \mathrm{m})$, cyanobacteria and ciliates were identified to the finest possible taxonomic level. The dinoflagellates were also examined to detect parasitism by Parvilucifera infectans; however, it should be noted that only the later stages of parasitism in the larger dinoflagellate species are possible to detect in lugol-fixed samples.

Single-cell sequencing and primer design. When this study was initiated, there was only a single Parvilucifera infectans 18S rRNA sequence in Genbank (www.ncbi.nlm.nih.gov/Genbank/, AF 133909). We used a mixed culture originating from a water sample off the Tasmanian coast to obtain additional $P$. infectans sequences. From this water sample, microscopically-identified as being rich in $P$. infectansinfected dinoflagellates, individual infected cells were picked with a sterile microcapillary pipette and washed once in sterile culture medium and once in sterile MQ-water, before being added to a sterile PCR reaction tube together with $2 \mu$ of sterile Q-grade water. The total volume for the subsequent PCR was $20 \mu \mathrm{l}$ and contained $100 \mathrm{nM}$ of each primer (EUK1272F, EUK2R; Table 1), $200 \mu \mathrm{M}$ of each dNTP, $1 \times$ PCR buffer (10 mM Tris- $\mathrm{HCl}, \mathrm{pH} \mathrm{9,} 50 \mathrm{mM} \mathrm{KCl}, 0.1 \%$ Triton X100; Invitrogen), $2 \mathrm{mM} \mathrm{MgCl}_{2}$, and $0.25 \mathrm{U}-\mathrm{Taq}$ DNA polymerase (Invitrogen). Thermal cycling was carried out in a Robocycler gradient 96 (Stratagene) with an initial 8 min denaturation at $94^{\circ} \mathrm{C}$ followed by 40 subsequent amplification cycles $\left(30 \mathrm{~s}\right.$ at $94^{\circ} \mathrm{C}, 1 \mathrm{~min}$ at $58^{\circ} \mathrm{C}$, and $2 \mathrm{~min}$ at $72^{\circ} \mathrm{C}$ ) and a final 10 min extension at $72^{\circ} \mathrm{C}$. Eleven out of 18 infected cells produced an amplification product.
Assuming that infected cells would have parasite DNA content far in excess of host DNA, we directly sequenced the amplified 18S rRNA fragment using primer EUK1272F and the BigDye terminator kit version 3.1 (Applied Biosystems) on an ABI 3700 capillary sequencer (Applied Biosystems). Sequences were checked manually using the Chromas software (www.technelysium.com.au/chromas.html) and then imported to ARB and aligned using parsimony by means of the integrated aligner tool (Strunk \& Ludwig 1996) followed by manual alignment of the sequences to the existing Parvilucifera infectans sequence and related dinoflagellate sequences. The probe design tool integrated in ARB was then used to design primers matching the $P$. infectans sequences while having at least 2 mismatches to any closely related taxa. Two candidate probes (Parvi 1 and Parvi 2; Table 1) were $P$. infectans-specific when checked against all sequences in GenBank by using the nucleotide-nucleotide basic local alignment search tool (BLASTN) 2.2.1 (www. ncbi.nlm.nih.gov/blast/). Parvi 1 and Parvi 2 were selected for further empirical tests. Possible amplification of non-target templates was investigated by constructing clone libraries from 3 positive samples (see 'Cloning and sequence analysis').

PCR-detection of Parvilucifera infectans in environmental samples. Plankton in mixed water samples, either from the $P$. infectans-positive Tasmanian culture or from Swedish coastal water samples, were collected by filtering variable amounts of water (1 to 4.5 l) onto a $47 \mathrm{~mm} 0.8 \mu \mathrm{m}$ membrane filter (Supor, Gelman) fitted in an acid-washed $(10 \% \mathrm{HCl})$ filter manifold. The filters were immediately frozen to $-80^{\circ} \mathrm{C}$ until further analyses. DNA from each filter was extracted and purified by bead-beating and solid phase extraction using the Ultra clean Soil DNA kit from MoBIO as recommended by the manufacturer (Eiler \& Bertilsson 2006). The quality and amount of extracted DNA was determined by agarose-gel electrophoresis (1\% agarose, $0.5 \times \mathrm{TBE}$ ) and subsequent detection with ethidium bromide and UV-transillumination and comparison to a $1 \mathrm{~kb}$ extension ladder (Invitrogen). The extracts usually contained 1 to $20 \mathrm{ng}$ DNA $\mu^{-1}$.

Table 1. Oligonucleotides used for PCR amplification, cloning and sequencing of 18S rRNA. na: not applicable, vector primers

\begin{tabular}{|lccc|}
\hline Primer & \multicolumn{1}{c}{ Sequence } & Escherichia coli position & Source \\
\hline EUK1272F & 5'-GCATGGCCGTTCTTA-3' & $1053-1067$ & Janson et al. (2000) \\
EUK2-R & 5'-TACGGAAACCTTGTTACGAC-3' & $1494-1513$ & Janson et al. (2000) \\
Parvi1-R & 5'-CCCATCACGACACAACTT-3' & $1287-1304$ & This study \\
Parvi2-R & 5'-TCCCCTCCAGATGACATT-3' & $1451-1458$ & This study \\
M13f-20 & 5'-GTAAAACGACGGCCAG-3' & na & Eiler \& Bertilsson (2004) \\
M13r & 5'-CAGG AAACAGCTATGAC-3' & na & Eiler \& Bertilsson (2004) \\
\hline
\end{tabular}


For each sample, 3 separate PCR reactions with different primer combinations were carried out in duplicate: EUK1272F-Parvi1-R, EUK1272F-Parvi2-R, and EUK1272F-EUK2R as a positive control (Table 1). For each primer pair, 1 negative control (Alexandrium sp.) and 1 positive control (DNA from the Tasmanian Parvilucifera infectans-enriched culture) were included. PCR amplification was carried out for approximately 5 ng of target DNA per reaction, and conditions were largely as described above for the EUK1272FEUK2-R primer pair, except that annealing temperature was optimised for higher stringency. Briefly, positive and negative controls were amplified in an annealing temperature gradient from 52 to $63^{\circ} \mathrm{C}$. The most stringent conditions (high annealing temperature) where a product was still visible for the positive control $\left(54^{\circ} \mathrm{C}\right.$ for both primer pairs) were chosen for all subsequent screening. Subsequent tests carried out with a gradient of extracted DNA from the Tasmanian culture (0.5 pg to $5 \mathrm{ng}$ ) showed that the PCR method produced a positive signal from less than $0.5 \mathrm{pg}$ of DNA, which corresponded to $<1$ dinoflagellate cell infected by $P$. infectans, or to 2 to 3 zoospores as estimated from microscopic counts. Tests carried out with a single infected dinoflagellate (see above), also produced a positive signal. The PCR-produced amplicons ranged in size from 360 to $600 \mathrm{bp}$ depending on the specific primer pair. Hence, for detection, PCR products $(20 \mu$ l of the reaction mix) were separated by electrophoresis in a $1 \%$ agarose, $0.5 \times \mathrm{TBE}$ gel. The gel was stained with ethidium bromide and bands were identified by UV-transillumination and image capture on a monochrome 12-bit cooled CCD camera (Coolsnap Pro CF, Media Cybernetics) equipped with ethidium bromide filters. Amplicon size was determined by comparison to a $100 \mathrm{bp}$ DNA ladder (Invitrogen). The criteria used for presence of $P$. infectans in the sample were that all 3 primer combinations produced a clearly visible band of the correct size.

Cloning and sequence analysis. PCR-amplified $18 \mathrm{~S}$ rRNA fragments from 3 positive samples (Skagerrak A, 8 July; Skagerrak B, 25 August; Skagerrak C, 7 July) were cloned. A sample from the northern Baltic proper (Stn C, 10 August) that was positive for all 3 primer pairs but produced amplicons of incorrect size was also cloned. In brief, PCR products from primer combination EUK1272F and Parvi2-R were purified by agarose gel electrophoresis and subsequent gel extraction using the Qiaquick kit (Qiagen). Purified DNA (5 to $10 \mathrm{ng}$ ) was cloned into the PCR 4-TOPO-TA vector for sequencing (Invitrogen) and transformed into competent Escherichia coli One Shot TOP10 cells as recommended by the manufacturer. Extracted plasmid from at least 35 positive clones from each library was used as a template in subsequent PCR amplification of the insert using the vector primers M13f-20 and M13r to avoid co-amplification of E. coli host-cell DNA. PCR amplification was 25 cycles as previously described (Eiler \& Bertilsson 2004). At least 4 clones from each library were sequenced on an ABI 3700 sequencer (Applied Biosystems) using primer M13f and the BigDye terminator kit version 3.1 (Applied Biosystems). All sequences were imported into ARB (Strunk \& Ludwig 1996) and aligned using the integrated aligner tool and the fast aligner option, followed by manual alignment of the sequences to closely related sequences with secondary structure of rRNA taken into account. Phylogenetic analyses were performed with ARB (Strunk \& Ludwig 1996) using Maximum Likelihood (Felsenstein 1981), taking E. coli position 1054-1450 into account. Robustness of the tree topology was confirmed by maximum parsimony with 100 bootstrap replications (Felsenstein 1985).

Principal component analysis. The Unscrambler 6 software (Camo AS) was used for principal component analysis (PCA) to correlate environmental state variables for the coastal stations and group the stations accordingly. A set of 20 physical, chemical and biological variables were included in the model (see Figs. 2 \& 3 , Table 2 ). These variables were centred at 0 and normalized to the variance prior to the analysis. Full cross validation was used, excluding 1 sample at the time. The response parameter for each excluded sample was predicted from a PCA model created from the remaining samples.

\section{RESULTS}

\section{Temperature and salinity}

Samples collected along the Swedish coastline represented a salinity gradient from 2 to $30 \%$ (Table 2 ). Depth average temperatures were ca. 12 to $18^{\circ} \mathrm{C}$ during the whole sampling period, with generally increasing temperatures over time at all regions (Table 2). Temperatures were comparable among areas, except in the central Baltic proper and the deep stations in the Bothnian Sea, and Bothnian Bay where July temperatures were low compared to other regions (Fig. 1, Table 2).

\section{Oxygen}

Skagerrak had lower oxygen concentration (5.5 to $8.2 \mathrm{mg} \mathrm{l}^{-1}$ ) compared to the Bothnian Sea and Bothnian Bay (8.3 to $11.6 \mathrm{mg} \mathrm{l}^{-1}$ ), except in June when values were in the same range (Table 2). One station in the Bothnian Bay (Stn B, Fig. 1) had markedly higher values than the other stations. 







\section{Nutrients}

TOC concentration was much lower in Skagerrak (ca. 2 to $3 \mathrm{mg} \mathrm{C}^{-1}$ ) compared to all other areas (ca. 4 to

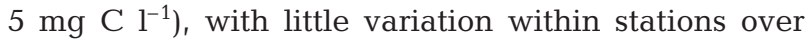
time (Table 2). Highest Tot-N concentrations were found in the northern Baltic proper in August (0.23 to $\left.0.26 \mathrm{mg} \mathrm{N}^{-1}\right)$, and lowest in Skagerrak in July (0.085 to $0.12 \mathrm{mg} \mathrm{N}^{-1}$; Table 2). Highest Tot-P concentrations were found in Skagerrak in June and August (ca. $40 \mu \mathrm{g}$ $\mathrm{P}^{-1}$; Table 2), and ca. 10-fold lower Tot-P concentrations were found in the Bothnian Bay (4 to $6 \mu \mathrm{g} \mathrm{P} \mathrm{l}^{-1}$ ).

\section{Bacteria}

Highest bacterial numbers were found in the northern Baltic proper $\left(\sim 3 \times 10^{9}\right.$ cells $\left.\mathrm{l}^{-1}\right)$, and lowest in Skagerrak at Stns B and C in July $\left(5.2 \times 10^{8}\right.$ to $7.8 \times$ $10^{8}$ cells $1^{-1}$; Table 2). The innermost station (Stn A) in Skagerrak had markedly higher values throughout the season.

\section{Chl $a$ and secchi depth}

Lowest chl a concentrations were generally found in Skagerrak during the whole sampling period, except for Stn A in August that was among the highest recorded ( $6 \mu \mathrm{g} \mathrm{l}^{-1}$; Table 2$)$. Note, however, that the variation was high both among days and stations in June in this area. Two stations (A and B) in the northern Baltic proper also had high values in July $\left(\sim 6 \mu \mathrm{g}^{-1}\right)$.

Secchi depth was generally highest in Skagerrak, with little variation over time (Table 2). The northern Baltic proper had low values ( 2 to $3 \mathrm{~m}$ ) both in July and August, except for the station furthest from land (Stn C) in August that had a secchi depth of $5.7 \mathrm{~m}$. Secchi depth in the Bothnian Sea and Bothnian Bay varied between 2.5 and $5.5 \mathrm{~m}$.

\section{Phytoplankton (>15 $\mu \mathrm{m})$}

The phytoplankton community in Skagerrak was totally dominated by dinoflagellates throughout the whole sampling period, except in August at Stn A when diatoms dominated (Table 3). Similarly, Öresund and the Baltic proper regions had mainly dinoflagellates but the communities were more mixed with other flagellates, in addition to the mainly autotrophic ciliate Myrionecta rubra (formerly Mesodinium rubrum) in Öresund and cyanobacteria in the Baltic proper, respectively (Table 3). The Bothnian Sea and Bothnian Bay were even less dominated by dinoflagellates, which accounted for at most 40 and $30 \%$ of the phytoplankters $>15 \mu \mathrm{m}$ in the Bothnian Sea and Bothnian Bay, respectively.

Total dinoflagellate numbers were highest in July at Stn A in Skagerrak, and in the northern Baltic proper (max. 90 cells $\mathrm{ml}^{-1}$; Fig. 2A). Most dinoflagellates throughout the whole season were small $(<25 \mu \mathrm{m})$ Alexandrium spp., Gymnodinium spp. and HeteroCapsa spp. (Fig. 2B). In June, there were also peaks of Protoperidinium/Gonyaulax spp., Ceratium spp. and Gyrodinium spp. (Fig. 2C-E). Dinophysis spp. peaked in July, whereas Prorocentrum spp. were abundant both in July and August (Fig. 2F-G). Amphidinium/ Katodinium spp. were present in similar abundances throughout the season (Fig. 2H).

\section{Microzooplankton (ciliates)}

Highest abundances of ciliates, especially large ciliates $(>20 \mu \mathrm{m})$, were found in Skagerrak in June, and also in the northern Baltic proper in August (Fig. 3). Note, however, that there was great variation among stations in Skagerrak. For the remaining study areas, there were generally low abundances of ciliates



\section{Parasite detection}

The parasite Parvilucifera infectans was detected by PCR at all 3 stations in Skagerrak on 7 and 8 July, as well as in August, but not in the June samples, suggesting seasonal dynamics in its presence (Table 2). Note that some samples from the northern Baltic proper, Bothnian Sea and Bothnian Bay also had positive amplifications (Table 2). However, these were not counted as $P$. infectans positive samples because the bands were 50 to $100 \mathrm{bp}$ larger than expected. Sequence analysis confirmed that it was not $P$. infectans (see below). Presence of $P$. infectans in Skagerrak was confirmed by microscopy in samples from July (Stns A and B, infected Ceratium tripos, Dinophysis acuminata, D. acuta, D. norvegica and late stages of infection when the host is no longer visible, i.e. sporangia), but not in August. The difficulty in discovering this parasite with microscopy is one possible reason why we could not detect it using this method in August, but it can also indicate lower abundance of the parasite at that time. The amount of PCR products of P. infectans was also lower in August compared to July.

The Parvilucifera infectans-positive stations was characterized by high salinity, high temperature and low levels of bacteria and nutrients (Table 2). This is also revealed by scores in the principal component 
Table 3. Abundances of major phytoplankton groups (>15 $\mu \mathrm{m})$ at stations sampled from June to August 2004. ${ }^{\mathrm{a}}$ : Myrionecta rubra (formerly Mesodinium rubrum), a mainly autotrophic ciliate

\begin{tabular}{|c|c|c|c|c|c|c|c|}
\hline Station & Date & $\begin{array}{l}\text { Dinoflagellates } \\
\left(\text { cells } \mathrm{ml}^{-1}\right)\end{array}$ & $\begin{array}{l}\text { Other flagellates } \\
\quad(\text { cells ml-1) }\end{array}$ & $\begin{array}{l}\text { Diatoms } \\
\left(\text { cells ml }{ }^{-1}\right)\end{array}$ & $\begin{array}{l}\text { Green algae } \\
(\text { cells ml-1) }\end{array}$ & $\begin{array}{l}\text { Cyanobacteria } \\
\left(\text { cells } \mathrm{ml}^{-1}\right)\end{array}$ & $\begin{array}{l}\text { M. rubra } \\
\left(\text { cells ml }{ }^{-1}\right)\end{array}$ \\
\hline \multirow{7}{*}{ Skagerrak A } & 6 Jun & 51 & 0 & 0.4 & 0 & 0 & 3.4 \\
\hline & 8 Jun & 29 & 0 & 0.11 & 0 & 0 & 2.94 \\
\hline & 9 Jun & 32 & 0 & 0.00 & 0 & 0 & 4.25 \\
\hline & $7 \mathrm{Jul}$ & 88 & 0.73 & 0.73 & 0 & 0 & 0.25 \\
\hline & $8 \mathrm{Jul}$ & 34 & 0 & 0 & 0 & 0 & 0.10 \\
\hline & 25 Aug & 6.9 & 0.019 & 0.17 & 0 & 0 & 0 \\
\hline & 26 Aug & 1.4 & 0 & 5.8 & 0 & 0.020 & 0 \\
\hline \multirow[t]{7}{*}{ Skagerrak B } & 6 Jun & 24 & 0 & 3.60 & 0 & 2.63 & 0.31 \\
\hline & 8 Jun & 9.2 & 0 & 0.42 & 0 & 0 & 0.74 \\
\hline & 9 Jun & 26 & 0 & 0.24 & 0 & 0 & 2.08 \\
\hline & $7 \mathrm{Jul}$ & 38 & 0.076 & 0.40 & 0 & 0 & 0.057 \\
\hline & $8 \mathrm{Jul}$ & 19 & 0 & 0 & 0 & 0 & 0.29 \\
\hline & 25 Aug & 16 & 0 & 0.10 & 0 & 0 & 0 \\
\hline & 26 Aug & 6.4 & 0.10 & 0.019 & 0 & 0 & 0.67 \\
\hline \multirow[t]{7}{*}{ Skagerrak C } & 6 Jun & 28 & 0 & 0.84 & 0 & 0 & 0.31 \\
\hline & 8 Jun & 23 & 0 & 0.14 & 0 & 0 & 1.71 \\
\hline & 9 Jun & 10 & 0.06 & 0.63 & 0 & 0 & 5.74 \\
\hline & $7 \mathrm{Jul}$ & 22 & 0 & 0.11 & 0 & 0 & 0.15 \\
\hline & $8 \mathrm{Jul}$ & 11 & 0 & 0 & 0 & 0 & 0.28 \\
\hline & 25 Aug & 19 & 0 & 0.013 & 0 & 0 & 1.1 \\
\hline & 26 Aug & 5.5 & 0 & 0.025 & 0 & 0 & 1.9 \\
\hline Öresund & 5 Aug & 9.3 & 7.2 & 0 & 0 & 0 & 2.8 \\
\hline Central Baltic proper & $27 \mathrm{Jul}$ & 14 & 0 & 0.025 & 0 & 6.0 & 0.25 \\
\hline \multirow[t]{2}{*}{ Northern Baltic proper A } & $13 \mathrm{Jul}$ & 63 & 0 & 0 & 0 & 72 & 9.0 \\
\hline & $10 \mathrm{Aug}$ & 12 & 0 & 0 & 0 & 19 & 6.5 \\
\hline \multirow[t]{2}{*}{ Northern Baltic proper B } & $13 \mathrm{Jul}$ & 76 & 0 & 0 & 0 & 56 & 7.3 \\
\hline & 10 Aug & 6.9 & 0.11 & 0.038 & 0 & 0 & 0 \\
\hline \multirow[t]{2}{*}{ Northern Baltic proper C } & $13 \mathrm{Jul}$ & 79 & 0 & 0 & 0 & 26 & 0.98 \\
\hline & 10 Aug & 75 & 0 & 0 & 0 & 28 & 8.9 \\
\hline Bothnian Sea A & $27 \mathrm{Jul}$ & 2.7 & 1.4 & 0.57 & 0.038 & 4.3 & 30 \\
\hline Bothnian Sea B & $26 \mathrm{Jul}$ & 6.9 & 2.0 & 0.71 & 0 & 2.8 & 6.4 \\
\hline Bothnian Sea C & $26 \mathrm{Jul}$ & 21 & 4.4 & 1.1 & 0 & 9.8 & 10 \\
\hline Bothnian Bay A & $28 \mathrm{Jul}$ & 0.36 & 0.88 & 0.17 & 0.038 & 2.7 & 0.84 \\
\hline Bothnian Bay B & $29 \mathrm{Jul}$ & 6.8 & 0.50 & 0.21 & 0 & 1.0 & 12 \\
\hline
\end{tabular}

analysis, where occurrence of $P$. infectans was positively related to salinity, temperature and the occurrence of various potential host dinoflagellates, e.g. Prorocentrum spp. and Ceratium spp., but negatively related to TOC, Tot-N, bacteria, oxygen and chl a concentration in the water (Fig. 4). Total dinoflagellate abundance, which was dominated by smaller species, was poorly correlated with the presence of $P$. infectans (Fig. 4). Scores of samples from the different regions clearly show that Skagerrak is different from the various basins of the Baltic Sea, with the first principal component reflecting the inverse patterns of higher salinity along the west coast and higher TOC concentrations in the Baltic region (Fig. 4). The samples from Skagerrak divided according to a temporal pattern with the samples from June, July, and August forming separate clusters, possibly in response to appearance of host organisms (Fig. 4). In the Baltic Sea, there was instead separation of samples primarily according to geographic position of sampling stations (Fig. 4).

\section{Diversity of Parvilucifera infectans}

The partial $P$. infectans $18 \mathrm{~S}$ rRNA sequences obtained from the different positive Skagerrak stations (A-C) taken on 3 sampling occasions (7 July, 8 July, 25 August) were almost identical to the previously reported 18S rRNA sequence reported for a Swedish isolate (AF133909; Norén et al. 1999). The only exceptions were 2 sequences from Skagerrak Stns B and C, which both carried a single identical insert at Escherichia coli position 1380 and a mismatch at E. coli position 1341 (LiUUSC 16, LiUU-SC 14; Fig. 5). The 4 sequences obtained 
Total Dinoflagellates

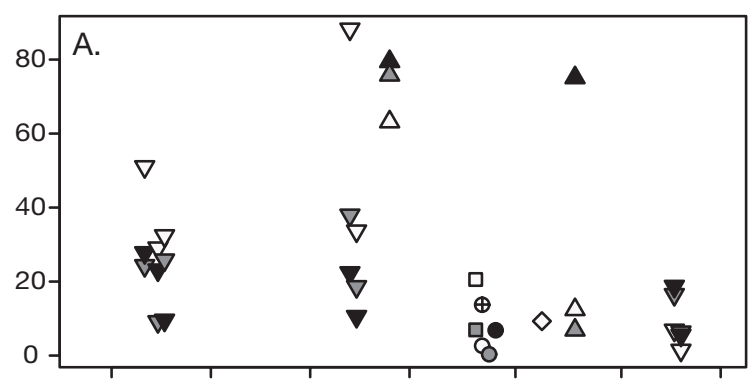

Protoperidinium spp., Gonyaulax spp.

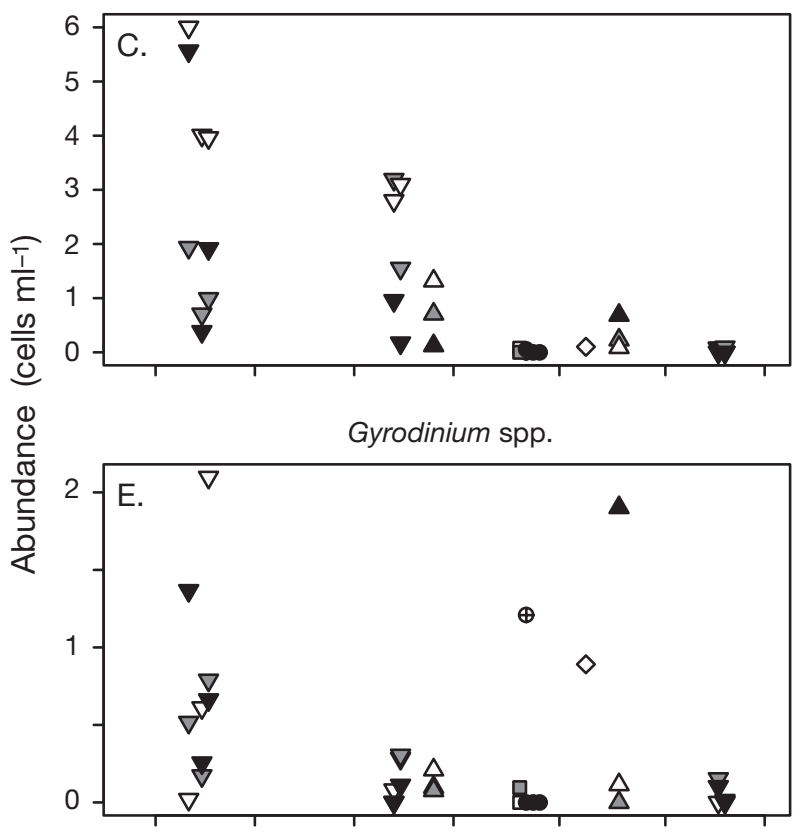

Prorocentrum spp.

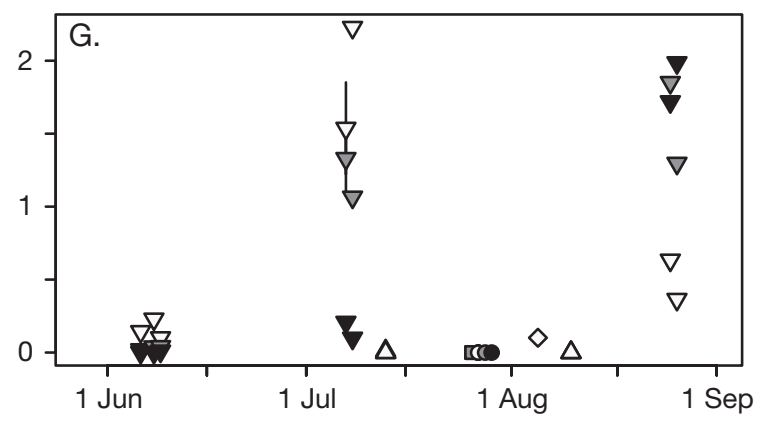

Alexandrium spp., Gymnodinium spp., Heterocapsa spp.

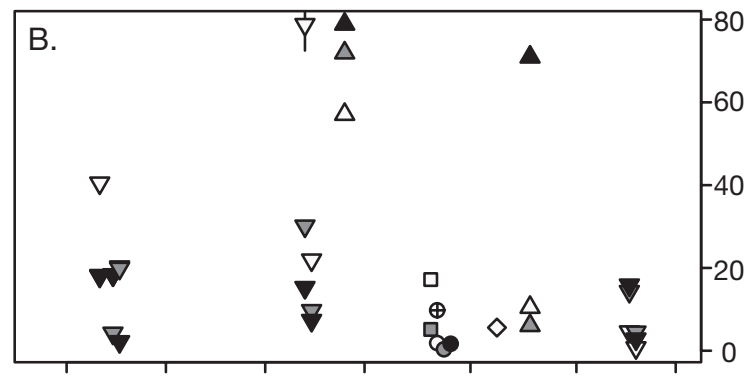

Ceratium spp.
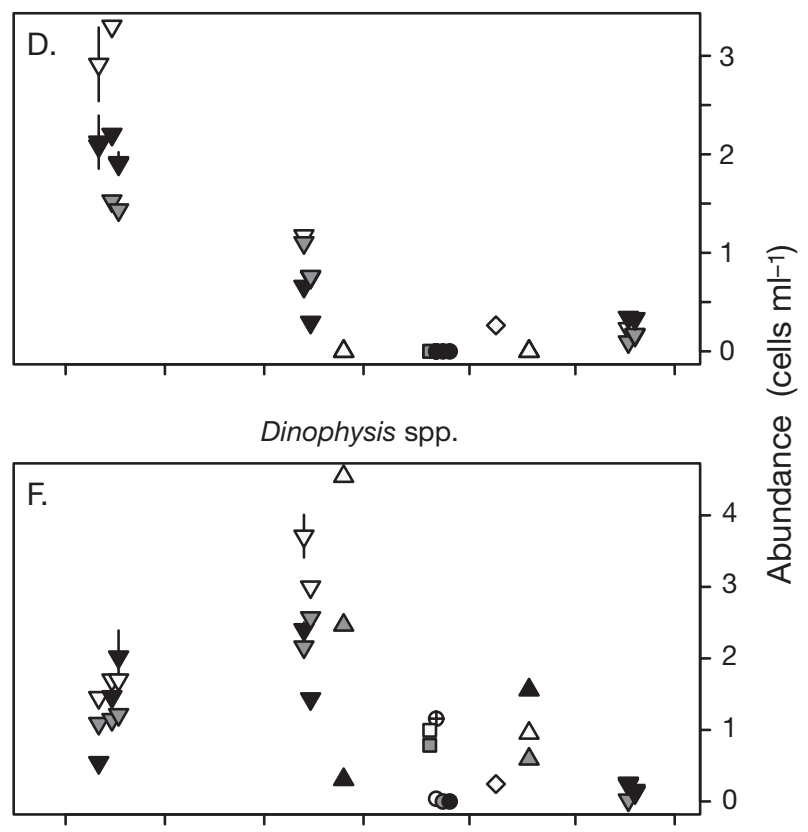

Katodinium spp., Amphidinium spp.

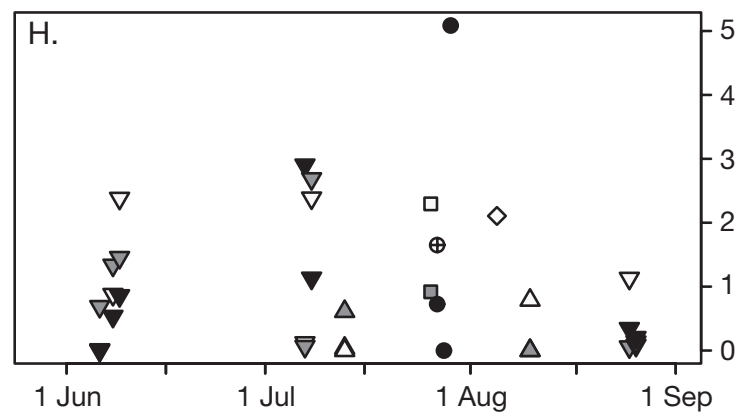

- Bothnian Bay A

- Bothnian Bay B

Bothnian Sea A

- Bothnian Sea B

- Bothnian Sea C

$\diamond$ Öresund

$\nabla$ Skagerrak A

$\nabla$ Skagerrak B

$\nabla$ Skagerrak $C$

$\oplus$ Central Baltic proper $\triangle$ Northern Baltic proper A

$\triangle$ Northern Baltic proper B

- Northern Baltic proper C

Fig. 2. Abundance of dinoflagellates (cells $\mathrm{ml}^{-1}$ ) at different sampling stations from June to August 2004. Vertical lines are SD.

(A) Total dinoflagellates, (B) Alexandrium spp., Gymnodinium spp. and Heterocapsa spp., (C) Protoperidinium/Gonyaulax spp., (D) Ceratium spp., (E) Gyrodinium spp., (F) Dinophysis spp., (G) Prorocentrum spp., (H) Katodinium/Amphidinium spp. 
from Tasmanian single infected cells (LiUU-HOB 6, 8, 9 and 10) were also nearly identical to the Swedish sequences, with 2 gaps at position 1093 and 1101 (Fig. 5). The somewhat longer sequences obtained from the northern Baltic proper (Stn C) were most closely related to Amphidinium belauense, L13719 (LiUU-NBP; Fig. 5), and the Parvi2-R binding site was identified in the internal transcribed spacer (ITS) region.

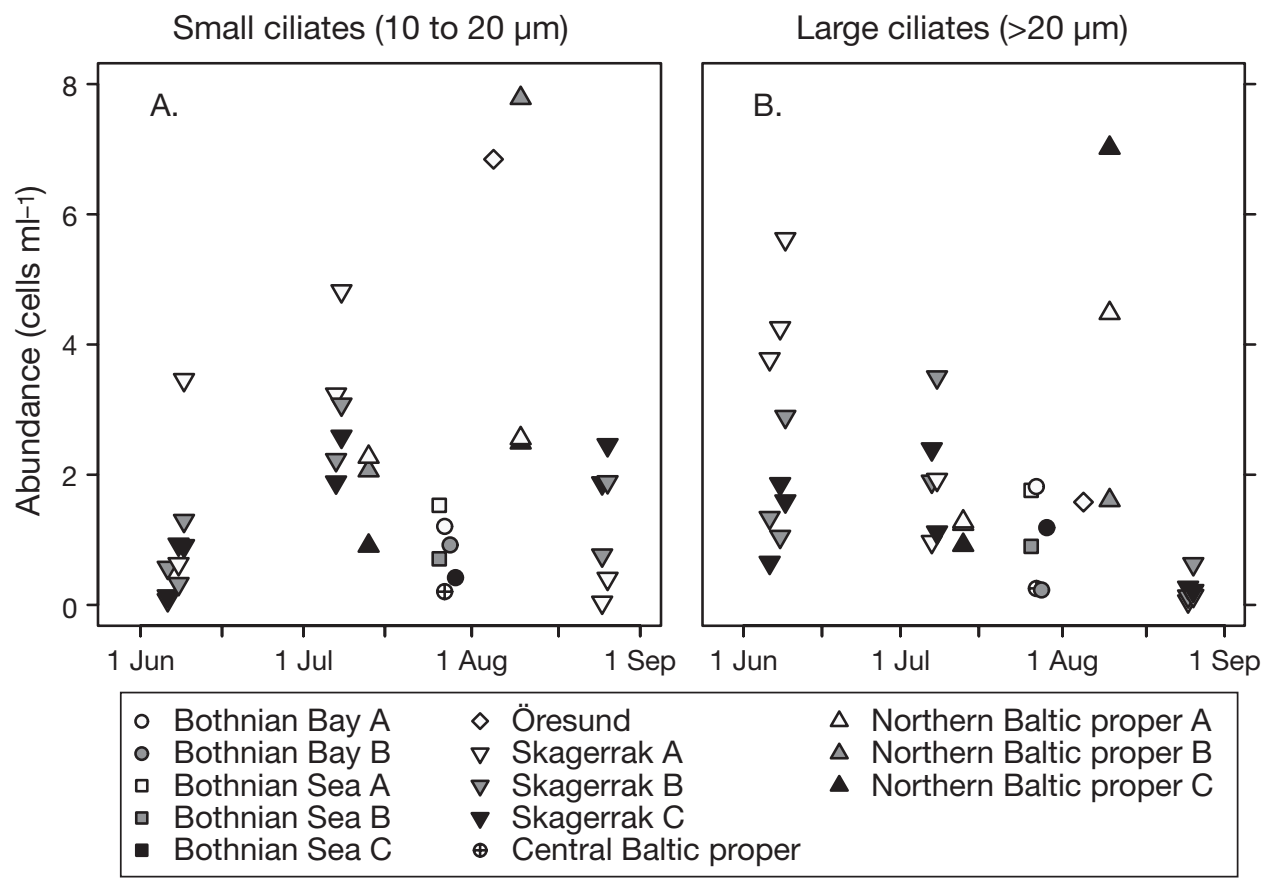

Fig. 3. Abundance (cells ml ${ }^{-1}$ ) of (A) small (10 to $\left.20 \mu \mathrm{m}\right)$ ciliates, and (B) large (>20 $\left.\mu \mathrm{m}\right)$ ciliates, at different sampling stations from June to August 2004

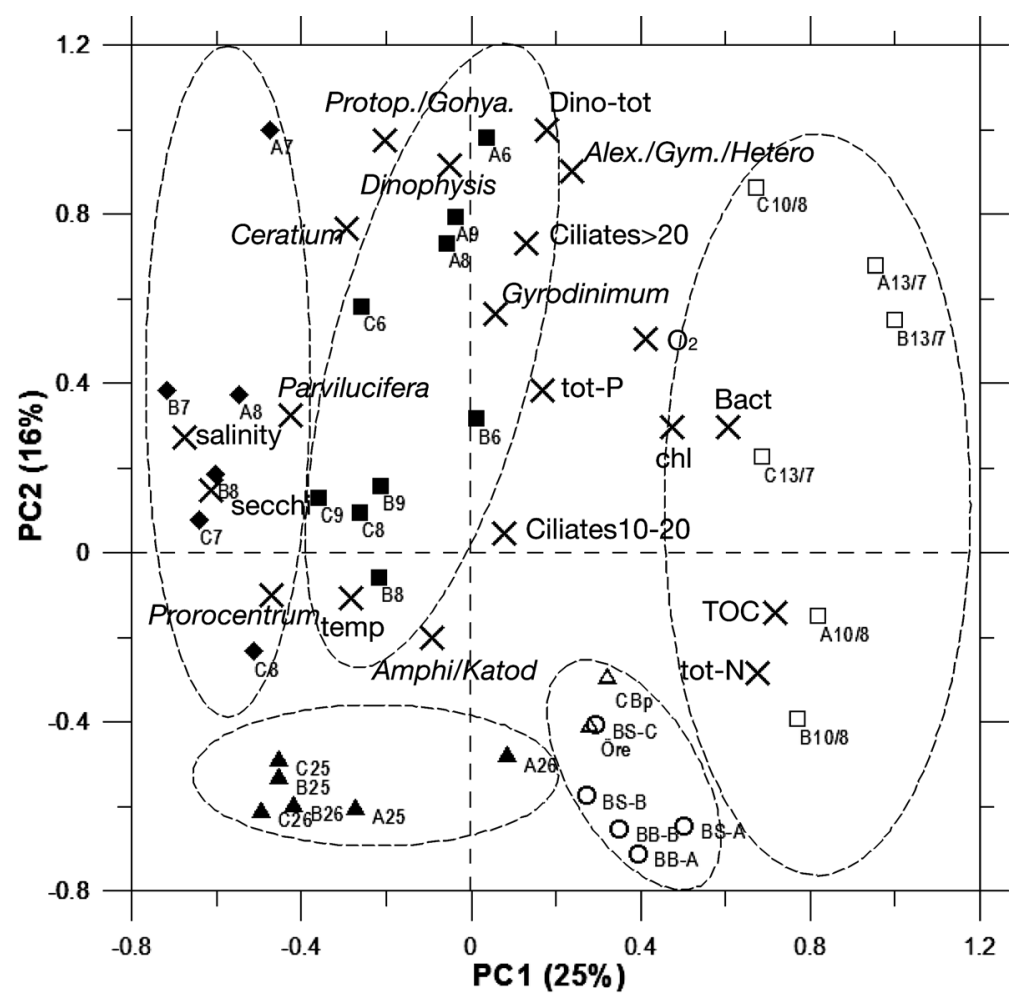

Fig. 4. Principal component analysis (PCA) of chemical and biological variables for sampled stations. First 2 principal components (PCs) are shown. Loadings $(X)$ and scores, i.e. stations, are shown in the same bi-plot, with locations given as A-C with adjacent label for date (see

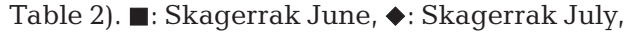
A: Skagerrak August, $\Delta$ : Öresund (Öre) and central Baltic proper (CBp), $\square$ : northern Baltic proper, O: Bothnian Sea (BS) and Bothnian Bay (BB). Dashed lines (ovals) were added to show clusters of different stations. Samples from Skagerrak cluster to the left, with different months clustered separately: July upper left, June upper middle, August lower left. The northern Baltic proper stations cluster to the right; remaining stations to the lower right. Protop.: Protoperidinim spp., Gonya.: Gonyaulax spp., Dino-tot: total dinoflagellates, Alex.: Alexandrium spp., Gym.: Gymnodinium spp., Hetero: Heterocapsa spp., Ciliates > 20: ciliates $>20 \mu \mathrm{m}$, Ciliates 10 to 20: ciliates 10 to $20 \mu \mathrm{m}$, chl: chl a, Bact: Bacteria, Amphi: Amphidinium spp., Katod: Katodinium spp., tot-P: total phosphorus, tot-N: total nitrogen, TOC: total organic carbon 


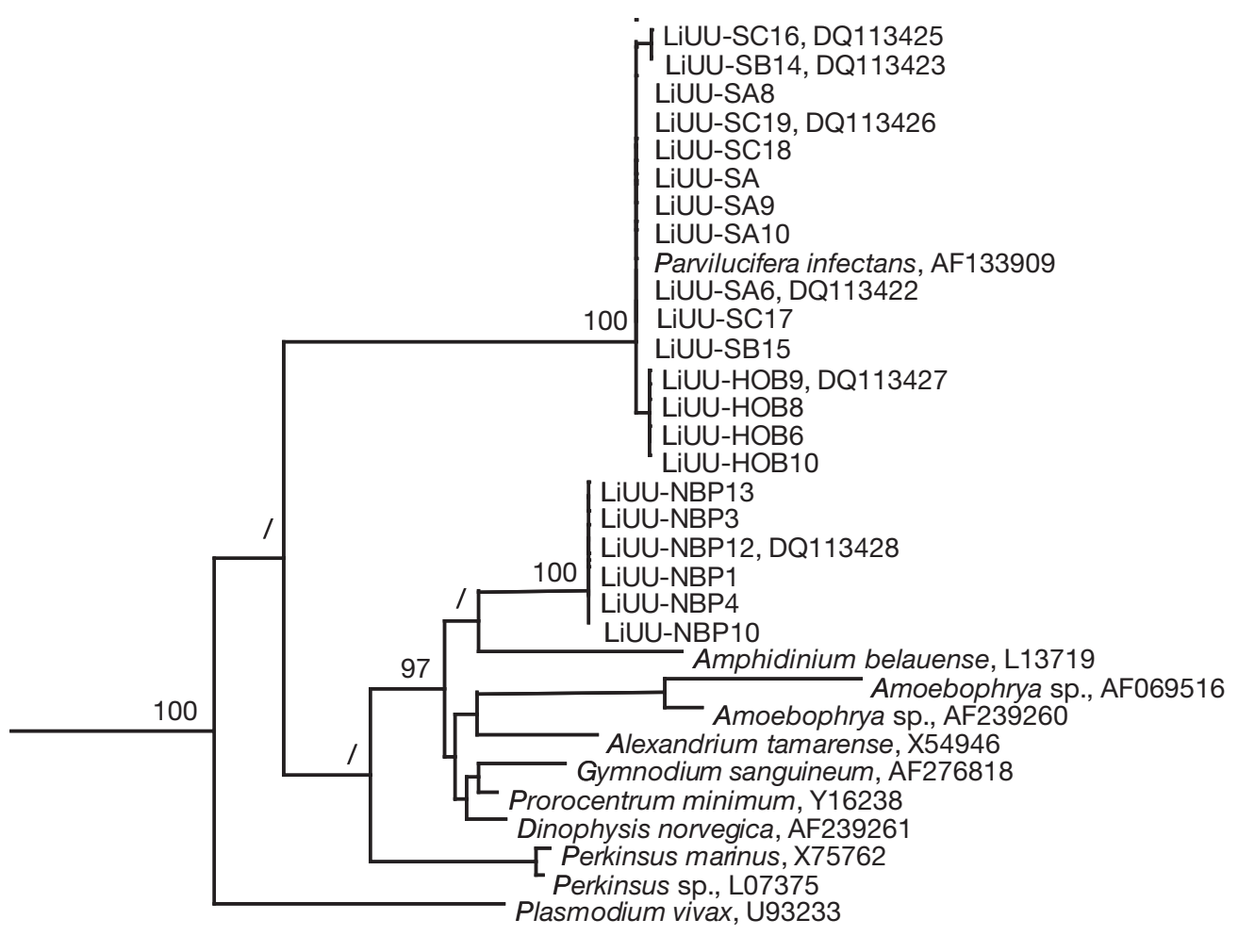

0.1

Fig. 5. Maximum likelihood tree of $\sim 500 \mathrm{bp} 18 \mathrm{~S}$ rRNA fragment from Parvilucifera infectans and related species. Robustness of tree topology confirmed by maximum parsimony with 100 bootstrap replications. Bootstrap supports above $50 \%$ given as numbers at nodes, otherwise designated as /. Genbank accession numbers given for sequences reported to Genbank. Scale: $10 \%$ sequence divergence, LiUU-NBP: clones from EUK1272F-Parvi2 positive sample in the northern Baltic proper (Stn C, August 10), LiUU-HOB: sequences from single cell-amplifications with EUK1272F-EUK2R of $P$. infectans-positive water from Tasmania (Australia),

LiUU-S (A-C): clones from 3 EUK1272F-Parvi2 positive samples in Skagerrak (Stn A, 8 July; Stn B, 7 July; Stn C, 25 August)

\section{DISCUSSION}

The novel PCR-based method to detect the dinoflagellate parasite Parvilucifera infectans presented here enabled us to monitor the presence of the parasite around the Swedish coastline. The analysed samples comprise gradients in salinity, TOC concentration, nutrients, presence of potential host and predator organisms and temperature, allowing us to judge the importance of these factors for the occurrence of $P$. infectans. We found the parasite only in the Skagerrak area, where it was originally discovered in Sweden (Norén et al. 1999), and where it has previously been observed by microscopy (M. Johansson unpubl. data). We were not able to find any positive samples in the Baltic region, even though samples were taken from 13 different stations on 15 different days during the same season when parasites were found in Skagerrak. Microscopic analysis supports the PCR-method: $P$. infectans was observed in Skagerrak but not in the Baltic Sea. Hence, it is likely that this parasite is not present in the Baltic Sea, or is at least not common.
Furthermore, in Skagerrak, the parasite was only detected in July and August; none of the 3 stations or 3 days sampled in June contained any detectable $P$. infectans, suggesting seasonal variation.

Apart from the Swedish west coast (Skagerrak \& Kattegatt), Parvilucifera infectans-like parasites have previously been detected in the North Sea (Norwegian west coast and off the Danish coast), Atlantic coast, Mediterranean Sea, Indian Ocean, eastern North America (Narragansett Bay), Australia, and off the southern coast of Korea (Norén et al. 2000, Park et al. 2004, Salomon 2004). These waters are all saline (>20\%) and the parasites were found during the summer or at average temperatures $>14^{\circ} \mathrm{C}$. P. infectans was found under the same conditions in this study: only at the most saline region and at temperatures above $14^{\circ} \mathrm{C}$ (Table 2 ). Hence, both salinity and temperature were positively related to the occurrence of $P$. infectans (Fig. 4). However, temperature alone could not explain spatial variation in parasite prevalence, because equally high temperatures were found in Öresund and in the Baltic Sea areas. Temperature could, 
however, in part explain temporal variation in parasite prevalence in Skagerrak, because July and August temperatures were higher (ca. 16 to $17^{\circ} \mathrm{C}$ ) than in June (ca. $14^{\circ} \mathrm{C}$ ). Norén et al. (1999) found $P$. infectans in Dinophysis spp. only when temperatures exceeded $15^{\circ} \mathrm{C}$. Furthermore, preliminary studies of parasite infection by $P$. infectans show that parasites incubated at $20^{\circ} \mathrm{C}$ had approximately 4 times higher infection success compared to parasites incubated at $14^{\circ} \mathrm{C}$, and that infection was also much faster (M. Johansson unpubl. data). Hence, temperature does not appear to be a crucial factor for controlling the observed spatial distribution of $P$. infectans, but could be a factor controlling seasonal variation.

The Parvilucifera infectans-positive samples in Skagerrak had generally lower nutrient concentrations (organic carbon, nitrogen, phosphorus) compared to other samples, and also generally lower bacterial numbers. There are no previous studies of how the distribution of this parasite correlates with nutrients or bacteria. However, recent controlled laboratory studies of the eukaryotic dinoflagellate parasite Amoebophrya sp. have shown that high nutrient levels can promote infection (Yih \& Coats 2000). The contrasting pattern observed in the present field survey may be due to stronger control by other factors, but it can also be that nutrient depletion in situ may reduce the growth of hosts, which could lead to higher infection prevalence (Iblings et al. 2004). In the laboratory, high bacterial abundance correlates with a decrease in parasite infection success (M. Johansson pers. obs.), but it is not known how bacteria may affect $P$. infectans or other eukaryotic parasites.

In this study, Parvilucifera infectans was found at a station (Skagerrak Stn A) and time (July) when dinoflagellates were most abundant. However, on the same days, this parasite was also detected at Stns B and $\mathrm{C}$ where dinoflagellate abundances were equal to the June samples when no parasites were detected. Furthermore, the other sampling stations also had total dinoflagellate abundances similar to those at Skagerrak stations where the parasite was found. Thus, total dinoflagellate numbers alone cannot explain parasite prevalence in either time or space, even though both the present and previous studies have shown that this parasite can have many different dinoflagellates as hosts, including Alexandrium spp., Gymnodinium spp., Heterocapsa triquetra, Protoperidinium spp., Ceratium spp., Dinophysis spp. and Prorocentrum spp. (Nishitani et al. 1985, Berland et al. 1995, Delgado 1999, Norén et al. 1999, 2000, Erard-Le Denn et al. 2000).

At least some dinoflagellate species in which Parvilucifera infectans has been found previously were present at all sampled areas and at all times (Fig. 2).
Thus, assuming that $P$. infectans has low host specificity, the presence/absence of parasites in the different sampled areas, and at the different times, are not likely explained by lack of host species. It could, however, be argued that the parasite needs a threshold in abundance of hosts to successfully proliferate, since the survival of the infective stage of the parasite decreases within minutes outside the host (F. Norén pers. comm.). The lack of parasites in the Baltic Sea could not be explained by either lack of hosts or host abundance (Fig. 2). The same argument can be made for the seasonal difference in Skagerrak, because potential parasite hosts were also found in high numbers in June when no parasites were found (Fig. 2).

We only used two 18S rRNA sequences from Parvilucifera infectans to design the specific primers used in this study. The partially sequenced 18S rRNA of these 2 isolates, collected from Kattegatt (Sweden) and Tasmanian coastal waters (Australia), differ only in 2 nucleotide positions. This implies a low degree of genetic differentiation, but we cannot rule out the possibility that our PCR-based analysis could have failed to detect some more divergent $P$. infectans populations. These 2 isolates are the only $18 \mathrm{~S}$ rRNA genes from $P$. infectans-like parasites sequenced to date, but the consistent sequence difference between parasites from the 2 stations may still suggest the existence of geographically isolated $P$. infectans populations that may differ in ecology and host-specificity. This has been found for the more intensely studied dinoflagellate parasite Amoebophrya spp. (Gunderson et al. 2002).

Predation by microzooplankton (i.e. ciliates) on the infective stage of the parasite may also restrict parasite infection. This has been shown for Amoebophrya spp. (Maranda 2001, Johansson \& Coats 2002), and in preliminary studies of Parvilucifera infectans where large ciliates (ca. $50 \mu \mathrm{m})$, but not small (ca. $25 \mu \mathrm{m}$ ), could decrease parasite infection (M. Johansson unpubl. data). For Skagerrak, the highest abundance of large ciliate species was found in June, when parasites were not detected (Fig. 3). Hence, high predation pressure could have been a further reason for the absence of $P$. infectans at this time.

There can be multiple reasons for the apparent absence of Parvilucifera infectans in the Baltic Sea regions. It is always problematic to make reliable statements on the absence of an organism in a given area, and we can not ignore the fact that the survey lasted only 3 months during 1 summer, thus not providing a complete picture of temporal distribution. However, from the 13 stations sampled, 9 were located in the Baltic Sea, and approximately the same numbers of samples were taken from the most saline regions as from the brackish Baltic Sea regions during the same 
time-period. Nevertheless, $P$. infectans was not found in Baltic Sea regions. Furthermore, Salomon et al. (2003a) frequently sampled the Baltic Sea during 2 yr to study parasite infection in dinoflagellates using microscopic methods. They found the parasite Amoebophrya sp. but not $P$. infectans (Salomon 2004). As argued above, neither temperature nor grazing, nor presence of hosts can exclusively explain the spatial distribution of $P$ infectans. Potential host organisms were present at abundances comparable to those at the west coast, and temperatures were as high as in other regions where $P$. infectans has been shown to proliferate. The remaining major factor that correlated highly with the occurrence of $P$. infectans is salinity (Fig. 4). Considering that the correlations between $P$. infectans and factors such as temperature and host availability were not very strong, it appears reasonable that the distribution of $P$. infectans along the Swedish coast is constrained by salinity. An additional constraint on $P$. infectans in the Baltic regions could be that dinoflagellates were not as dominant in the total phytoplankton communities in the Baltic Sea areas relative to the Skagerrak area, even if absolute abundance was similar. The phytoplankton community was instead dominated by cyanobacteria, Myrionecta rubra (ciliata), flagellates other than dinoflagellates and diatoms. It is possible that the small infective parasites adsorb to other particles and are therefore prevented from reaching their hosts. However, this was not considered a crucial factor for the infective stage of the dinoflagellate parasite Amoebophrya spp. (Armstrong $\&$ Coats 2003).

In conclusion, when screening for the dinoflagellate parasite Parvilucifera infectans in a natural salinity gradient (2 to $30 \mathrm{ppt}$ ) along the Swedish coast, $P$. infectans was only found in the most saline region (Skagerrak), suggesting that it thrives only at salinities higher than those representative of the brackish Baltic region. Other factors that co-varied with the occurrence of $P$. infectans, including temperature, grazers and host organisms, did not appear to impose absolute constraints on its distribution. Our study reveals both spatial and temporal patchiness of $P$. infectans in coastal waters and also points to spatial isolation of distinct $P$. infectans populations, at least over longer geographic distances.

Acknowledgements. We thank Dr. F. Norén at N-research AB for kindly providing a Parvilucifera infectans-positive mixed culture from Tasmania, and B. Næslund, Department of Systems Ecology, Stockholm University, for excellent help during sampling and creation of figures. We are also grateful to Tjärnö Marine Biological Lab; Marine Biology Department, Campus Helsingborg; Department of Marine Sciences, Kalmar University; Department of Systems Ecology, Stockholm University; and UMF, Umeå University for their kind welcome and for providing help and equipment during sampling. This work was funded by the Swedish Research Council for Environment, Agricultural Sciences and Special Planning (FORMAS, grant 22.3/2003-0209 to M.J. and grant 2004-0634 to S.B.)

\section{LITERATURE CITED}

Armstrong TN, Coats DW (2003) Influence of suspended solids and host diversity on dinoflagellate parasitism. J Eukaryot Microbiol 50:23A

Berland BR, Maestrini SY, Grzebyk D (1995) Observations on possible life cycle strategies of the dinoflagellates Dinophysis cf. acuminata, Dinophysis acuta and Dinophysis pavillardi. Aquat Microb Ecol 9:183-189

Cachon J (1964) Contribution à l'étude des péridiniens parasites. Cytologie, cycles évolutifs. Ann Sci Nat Zool 6:1-158

Cachon J, Cachon M (1987) Parasitic dinoflagellates. In: Taylor FJR (ed) The biology of dinoflagellates. Blackwell Scientific, Oxford, p 571-610

Coats DW (1999) Parasitic life styles of marine dinoflagellates. J Eukaryot Microbiol 46:402-409

Coats DW, Bockstahler KR (1994) Occurrence of the parasitic dinoflagellate Amoebophrya ceratii in Chesapeake Bay populations of Gymnodinium sanguineum. J Eukaryot Microbiol 41:586-593

Coats DW, Park MG (2002) Parasitism of photosynthetic dinoflagellates by three strains of Amoebophrya (Dinophyta): parasite survival, infectivity, generation time, and host specificity. J Phycol 38:520-528

Coats DW, Adam EJ, Gallegos CL, Hedrick S (1996) Parasitism of photosynthetic dinoflagellates in a shallow subestuary of Chesapeake Bay, USA. Aquat Microb Ecol 11: $1-9$

Delgado M (1999) A new 'diablillo parasite' in the toxic dinoflagellate Alexandrium catenella as a possibility to control harmful algal blooms. Harmful Algae News 19:1-3

Del Giorgio PA, Bird DF, Prairie YT, Planas D (1996) The flow cytometric determination of bacterial abundance in lake plankton with the green nucleic acid stain SYTO 13. Limnol Oceanogr 41:783-789

Eiler A, Bertilsson S (2004) Composition of freshwater bacterial communities associated with cyanobacterial blooms in four Swedish lakes. Environ Microbiol 6:1228-1243

Eiler A, Bertilsson S (2006) Detection and quantification of Vibrio populations using denaturing gradient gel electrophoresis. J Microbiol Methods (in press)

Elbrächter M (1973) Population dynamics of Ceratium in coastal waters of the Kiel Bay. Oikos Suppl 15:43-48

Erard-Le Denn E, Chrétiennot-Dinet JM, Probert I (2000) First report of parasitism on the toxic dinoflagellates Alexandrium minutum Halim. Estuar Coast Shelf Sci 50:109-113

Felsenstein J (1981) Evolutionary trees from DNA sequences: a maximum likelihood approach. J Mol Evol 17:368-376

Felsenstein J (1985) Confidence limits on phylogenies: an approach using the bootstrap. Evolution 39: 783-791

Gisselson LÅ, Carlsson P, Granéli E, Pallon J (2002) Dinophysis blooms in the deep euphotic zone of the Baltic Sea: do they grow in the dark? Harmful Algae 1:401-418

Granéli W, Granéli E (1991) Automatic potentiometric determination of dissolved oxygen. Mar Biol 108:341:348

Granéli E, Sundström B, Edler L, Anderson DM (1987) Toxic marine phytoplankton. Elsevier Science Publishers, New York

Gunderson JH, John SA, Boman WC II, Coats DW (2002) Multiple strains of the parasitic dinoflagellate Amoebophrya 
exist in Chesapeake Bay. J Eukaryot Microbiol 49: 469-474

Holm-Hansen O, Riemann B (1978) Chlorophyll a determination: improvement in methodology. Oikos 30:438-447

Iblings BW, De Bruin A, Kagami M, Rijkeboer M, Brehm M, Van Donk E (2004) Host parasite interactions between freshwater phytoplankton and chytrid fungi (Chytridiomycota). J Phycol 40:437-453

Jansson S, Gisselson LÅ, Salomon PS, Granéli E (2000) Evidence for multiple species within the endoparasitic dinoflagellate Amoebophrya ceratii as based on 18S rRNA gene-sequence analysis. Parasitol Res 86:929-933

Jeong HJ, Shim JH, Lee CW, Kim JS, Koh SM (1999a) Growth and grazing rates of the marine planktonic ciliate Strombidinopsis sp. on red-tide and toxic dinoflagellates. J Eukaryot Microbiol 46:69-76

Jeong HJ, Shim JH, Kim JS, Park JY, Lee CW, Lee Y (1999b) Feeding by the mixotrophic thecate dinoflagellate Fragilidium cf. mexicanum on red-tide and toxic dinoflagellates. Mar Ecol Prog Ser 176:263-277

Jespersen AM, Christoffersen K (1987) Measurements of chlorophyll a from phytoplankton using ethanol as extraction solvent. Arch Hydrobiol 109:445-454

Johansson M, Coats DW (2002) Ciliate grazing on the parasite Amoebophrya sp. decreases infection of the red-tide dinoflagellate Akashiwo sanguinea. Aquat Microb Ecol 28:69-78

Kim MC, Yoshinaga I, Imai I, Nagasaki K, Itakura S, Ishida Y (1998) A close relationship between algicidal bacteria and termination of Heterosigma akashiwo (Raphidophyceae) blooms in Hiroshima Bay, Japan. Mar Ecol Prog Ser 170: 25-32

Maranda L (2001) Infection of Prorocentrum minimum (Dinophyceae) by the parasite Amoebophrya sp. (Dinoflagellea). J Phycol 37:245-248

Menzel DH, Corwin N (1965) The measurement of total phosphorus in seawater based on the liberation of organically bound fractions by persulphate oxidation. Limnol Oceanogr 10:280-282

Murphy J, Riley JP (1962) A modified single solution method for the determination of phosphate in natural waters. Anal Chim Acta 27:31-36

Nagasaki K, Tarutani K, Yamaguchi M (1999) Growth characteristics of Heterosigma akashiwo virus and its possible use as a microbiological agent for red tide control. Appl Environ Microbiol 65:898-902

Nishitani L, Erickson G, Chew KK (1985) Role of the parasitic dinoflagellate Amoebophrya ceratii in control of Gonyaulax catenella populations. In: Anderson DM, White AW, Baden DG (eds) Toxic dinoflagellates. Elsevier Science Publishers, New York, p 225-230

Norén F, Moestrup Ø, Rehnstam-Holm AS (1999) Parvilucifera infectans Norén et Moestrup gen. et sp. nov. (Perkinsozoa phylum nov.): a parasitic flagellate capable

Editorial responsibility: Edna Granéli, Kalmar, Sweden of killing toxic microalgae. Eur J Protistol 35:233-254

Norén F, Moestrup Ø, Rehnstam-Holm AS, Larsen J (2001) World-wide occurrence and host specificity of Parvilucifera infectans: a predatory flagellate capable of killing toxic dinoflagellates. In: Hallegraeff GM et al. (eds) Proc IX Conf Harmful Algal Blooms, Hobart, 7-11 Feb 2000. IOC of UNESCO, Paris

Park MG, Yih W, Coats DW (2004) Parasites and phytoplankton, with special emphasis on dinoflagellate infections. J Eukaryot Microbiol 51:145-155

Porter KG, Feig YS (1980) The use of DAPI for identifying and counting aquatic microflora. Limnol Oceanogr 25:843-948

Pouchet G (1885) Nouvelle contribution à l'histoire des Péridiniens marins. J Anat Physiol 21:28-88

Richardson K (1997) Harmful or exceptional phytoplankton blooms in the marine ecosystem. Adv Mar Biol 31:301-385

Salomon PS (2004) Importance of pathogens on the ecology of marine phytoplankton populations. $\mathrm{PhD}$ dissertation, Kalmar University, Kalmar

Salomon PS, Janson S, Granéli E (2003a) Parasitism of Dinophysis norvegica by Amoebophrya sp. in the Baltic Sea. Aquat Microb Ecol 33:163-172

Salomon PS, Janson S, Granéli E (2003b) Multiple species of the dinophagous dinoflagellate genus Amoebophrya infect the same host species. Environ Microbiol 5: $1046-1052$

Sengco MR, Coats DW, Popendorf KJ, Erdner DL, Gribble KE, Anderson DM (2003) Biological and phylogenetic characterization of Amoebophrya sp. ex. Alexandrium tamarense. 2nd Symp Harmful Marine Algae in the US, Dec 9-13, Woods Hole, Massachusetts. Available at http:// www.whoi.edu/redtide/2ndsymposium/All_abstracts.pdf

Strunk O, Ludwig W (1996) ARB: A software environment for sequence data, 2.1.1. Technical University of Munich, Munich

Taylor FJR (1968) Parasitism of the toxin-producing dinoflagellate Gonyaulax catenella by the endoparasitic dinoflagellate Amoebophrya ceratii. J Fish Res Board Can 25: 2241-2245

Utermöhl H (1958) Zur Vervollkommnung der quantitativen Phytoplankton-Methodik. Mitt Int Verein Theor Angew Limnol 29:117-126

Watras CJ, Garcon VC, Olson RJ, Chrisholm SW, Anderson DM (1985) The effect of zooplankton grazing on estuarine blooms of the toxic dinoflagellate Gonyaulax tamarensis. J Plankton Res 7:891-908

Wintermanns JFGM, DeMots A (1965) Spectrophotometric characteristics of chlorophyll- $a$ and $-b$ and their pheophytins in ethanol. Biochem Biophys Acta 109:448-453

Yih W, Coats DW (2000) Infection of Gymnodinium sanguineum by the dinoflagellate Amoebophrya sp.: effect of nutrient environment on parasite generation time, reproduction, and infectivity. J Eukaryot Microbiol 47: $504-510$

Submitted: December 20, 2005; Accepted: March 29, 2006

Proofs received from author(s): June 21, 2006 